
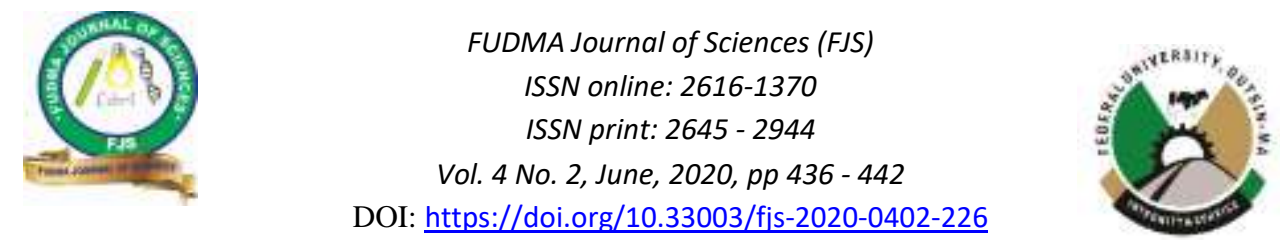

\title{
ECONOMIC ANALYSIS OF MARKETING EFFICIENCY OF PINEAPPLE IN KANO STATE MARKETS, NIGERIA
}

${ }^{1}$ Lawal A. T., ${ }^{1}$ Dambazau, S. A., ${ }^{2}$ Yusuf, A. O., ${ }^{1}$ Ahmad, Y. S., ${ }^{1}$ Adomi, A. A., ${ }^{3}$ Sadiq, M. S., ${ }^{1}$ Suleiman, I. and ${ }^{4}$ Barau, S. S.

\author{
${ }^{1}$ Department of Agricultural Economics and Extension, Kano Uni. Of Sci \& Tech, Wudil \\ ${ }^{2}$ Agricultural and Rural Management Training Institute (ARMTI), Ilorin, Kwara State, \\ ${ }^{3}$ Department of Agricultural Economics and Extension, Federal University, Dutse, Jigawa State,Nigeria \\ ${ }^{4}$ Department of Agricultural Economics and Extension, Federal University Dutsin-Ma, Katsina State, Nigeria
}

Corresponding Author's email: altaofeeq2000@yahoo.com, 08035820042

\begin{abstract}
The study analysed the marketing efficiency of pineapple in selected markets in Kano metropolis. Data was collected with the used of questionnaire and were analysed using descriptive statistics, market margin analysis and market efficiency. Results shows that the majority (33.3\%) of the respondents were within the ages of 4755 years, followed by $23.8 \%$ within the age range of $29-37$ years and 9.5\% of age range of 56-64 years were the minimum. Household size, in the wholesaler's side category 5-8 size had the highest members with $42.80 \%$, followed by $1-4$ and $17-20$ with $19.10 \%$ each, while $14.30 \%$ had 9-12 and the least was households within the range of 13-16 with only $4.8 \%$, while in the retailer's side category 1-5 size had the highest members with $40.90 \%$, followed by $11-15$ with $24.90 \%$, then $22.60 \%$ had $6-10$ while $9.10 \%$ had $16-20$ size and the least was household within the range of 21-25 with only $2.30 \%$. However, 31-37years category ranked the least with $4.80 \%$. On the retailers side the result reveals that $13-20$ years category ranked the highest with $41.00 \%$ and $37-44$ years category were the least with $6.80 \%$ each. The marketing margin analysis indicated that for every $14.4 \mathrm{~kg}$ pineapple, gross marketing margin of wholesalers 158.85 was higher than that of retailers 129.66 whereas net marketing margin of retailers with $\$ 91.24$ was higher than that of wholesalers with $\$ 59.09$, return on investment of retailers with 1.11 was also higher than that of wholesalers with 1.08 , and however, marketing margin of wholesalers with 20.03 is higher than that of retailers with 14 . This means that pineapple marketing in the study area was profitable. The marketing efficiency for $14.4 \mathrm{~kg}$ pineapple was highest with $337.48 \%$ for retailers while that of wholesalers was lower with $159.23 \%$. Generally, it can be deduced that among all the market participants, the overall marketing efficiency indicates that the markets were efficient. It can be concluded that pineapple marketing was profitable and efficient in the study area despite the constraints faced by the marketers. And therefore can be recommended that Construction of good road network to reduce damage of pineapple during transportation and plastics trays should be provided.
\end{abstract}

Keywords: Analysis, Efficiency, Pineapple, Marketing and Kano State

\section{INTRODUCTION}

Pineapple (Ananas comosus L.) Merr.) belongs to the family Bromeliaceae. It is known as the queen of fruits because of its excellent flavour and taste. According to Ubi et al. (2005), Pineapple is the third most important tropical fruit in world after Banana and Citrus (Bartholomew et al., 2003). Important producing countries are Brazil, India, China, Nigeria, Mexico and Colombia. They produce the fruit primarily for fresh fruit markets and processing industry. Pineapple as an economic crop has encouraging potentials for foreign exchange earnings. It can increase national income through the expansion of local industries and higher incomes for farmers involved in its production (Fawole, 2008). It is one of the crops with the most potential in the international market and highly profitable, an activity that demands a large workforce (Quijandria et al., 1997). Pineapple production therefore can be used as a panacea for food security and job creation, help in rural development, launch the country on the path of self-sufficiency, increase food production and help in improving lives and health care delivery services. Pineapple is a wonderful tropical fruit having exceptional juiciness, vibrant flavour and immense health benefits (Joy, 2010). It is grown both for the fresh and processed market, which makes it an important food which can be eaten fresh or eaten in a processed form (FAO, 2009).

Despite Nigeria's position and potential in pineapple production in the world and the enormous economic advantages the country has over the crop, Nigeria has the lowest productivity of 7 tons/ha when compared with the other nine top producers in the world thereby, contributing a small share $(5 \%)$ of the world pineapple production (FAOSTAT, 2010 and Mark, 2010) thus, reflecting a low yield in pineapple production in the country (Mark, 2010). Although Nigeria's position on the list of world pineapple producers is encouraging, majority of the harvested produce is wasted due to production inefficiencies, post-harvest losses, low level of technology to facilitate processing of quality pineapple products and inefficient marketing system (Ivan et al., 2011). Arable land in Nigeria is suitable for cultivating most types of crops implying the productivity potential of Nigeria is enormous, the share of global trade has declined to the point where little of Nigeria's Agricultural produce is seen in the World's markets which makes Nigeria the sleeping giant of Africa in Agriculture (Ken, 2009).

According to Khalid et al. (2007) in the past, relatively more emphasis is placed on enhancing the production and 
productivity of major crops by ignoring that of the horticultural crops, fruits inclusive. Though Nigeria occupy a notable position in pineapple production in Africa and the world at large, its inability to fully tap into the economic potentials of the crop might be a reflection of its inefficient nature in production which otherwise, would have served as an important tool in achieving some of the objectives of the transformation agenda in Nigeria. The objectives of the study are to describe the socio-economic characteristics of respondents and determine the marketing efficiency and marketing margin of pineapple marketing in Kano metropolis.

\section{METHODOLOGY}

\section{Study area}

The study was carried out in Yanlemu, Yankura and Kofaruwa markets. Yanlemu is a fruit market that is renowned for the sales of virtually all the fruits found in Kano State, the market is located at Na'ibawa along Zaria road, Kumbotso local government area, of Kano State. The market was established in 1984 at Kofar Nasarawa as a temporary site where they were together with the people selling kola nut before the market was later moved to Yanlemu as a permanent site about 29 years ago. The different types of fruits found in the market include pineapple, orange, banana, pawpaw, coconut and watermelon etc. and also meagre fraction of other people selling various kinds of commodities like roasted frog meat, fries yam, local blacksmiths, etc. Yanlemu market considered as the main depot where the major fruit dealers and suppliers sell to petty traders who in turn penetrate the metropolitan Kano and other local markets throughout the State and its neighbourhood. The market is a daily market comprising of wholesalers, retailers and consumers.

Yankura market is located at sabongari, fagge local government Kano state. It is a big market selling different types of products such as food stuffs (like fish, meat, sugar, flour, semovita), clothes, drugs, furniture's, vegetables and fruits, etc. The fruits sellers are located near Yankura pedestrian steel bridge of the market. Fruits marketers there started illegal during Buhari military regime until it became permanent around 1996. The market comprises of wholesalers, retailers and consumers and the market is a daily type.

Kofaruwa market is located opposite Tashar Kuka Kofaruwa, Dala local government Kano State. The market is a daily market selling various products such as flour, vehicles spare parts fruits etc. The market was established more than 29 years back. The fruits sellers where located opposite Tashar Kuka by the road side. The markets comprises of wholesalers, retailers and consumers.

\section{Sampling procedure}

This research work was conducted in three selected markets of Kano metropolis. The markets are Yanlemu, Yankura and Kofaruwa due to the high concentration of pineapple marketing. A pre-visit was conducted whereby Yanlemu market has estimated numbers of 50 and 100 wholesalers and retailers respectively, Yankura market has estimated numbers of 3 and 14 wholesalers and retailers respectively, and finally Kofaruwa market has estimated numbers of 15 and 34 wholesalers and retailers respectively. 30 per cent of the proportion was randomly selected as respondents, thereby having total of 21 and 44 wholesalers and retailers respectively, thereby making a total of sixty five (65) marketers as respondents.

$\begin{array}{llll}\text { Method of } & \text { Data } & \text { Collection } & \text { and } \\ \text { Analysis } & & & \end{array}$

The data for the study were collected from the primary source and was collected using structured questionnaire. The questionnaire was structured to reflect the objectives of the study. It contains sections where questions were asked on the objectives of the study such as socio economic characteristics, marketing margin and marketing efficiency. The data for this research was analysed using descriptive statistics, marketing margin and efficiency of pineapple marketers.

\section{Analytical Techniques \\ Descriptive Statistics}

These are concerned with scientific methods for summarizing presenting and analysing data as well as drawing valid conclusions and making reasonable decisions on the basis of such analysis. This is done with the aid of mean, percentage, frequency distribution etc

Mean; this is the sum values in the data group divided by the number of values it is the most useful and fundamental measure of location

$\overline{\mathrm{X}}=\frac{\Sigma \mathrm{f} \mathrm{x}}{\Sigma \mathrm{f}}$

Percentage; this is proportion obtained by dividing the number of observations in each class by the total number of observations multiplied by a hundred

percentage $=\frac{\text { actual change }}{\text { original amount }} \times 100$.

Frequency Distribution; this is an organized display of data set which falls into each mutually exclusive class. Therefore for easy comprehension of findings of this research and its contribution to knowledge it will be to grouped field data in the form of frequency distribution tables, bar charts, pie charts and percentage tables.

\section{Marketing margin}

This is the differences in prices of a commodity at different stages of time, place, form and possession as it moves from producer to the ultimate consumer. Olukosi et al. (2005) defined margin as the differences in prices between that paid by the consumers and that obtained by the producer. The study utilized the modified form of marketing margin model adopted by Olukosi et al. (2005), to determine the margin of the marketers in marketing system of pineapple in the study area. The model is specified as follows:

$M m=$
$\frac{S p-P p}{s p} \times 100$

Where:

$\underset{M m}{M a r g i n}$
$S p=$ Selling Price
$P p=$ Purchasing Price




\section{Marketing Efficiency}

Marketing efficiency is the maximization of out-input ratio. The output connotes consumer's satisfaction or utilities created in a marketing system, while the inputs are the different resources used. The cost is measurable but consumers' satisfaction or benefits cannot be easily measured. Despite this set back, it has been widely used to measure market performance. The efficiency of egg marketing in the study area will be measured using this model. The model is specified as

$\mathrm{ME}=\frac{\text { value added by marketing }}{\text { cost of marketing services }} \times 100$

Where; $\mathrm{ME}=$ marketing efficiency

Value added by marketing=retail price at consumers level less than producers price

Cost of marketing service $=$ service cost of performing various marketing.

The decision rule is that if; Marketing efficiency (ME) $>100$ implies positive returns to business.
While if; Marketing efficiency (ME) $<100$ implies negative returns to business

\section{RESULTS AND DISCUSSION}

Socio-Economic Characteristics of the Pineapple Marketers The socio-economic characteristics of the marketers usually assist in getting the clear understanding of the behaviour of the respondents. Moreover, several research findings have revealed that, the decision making process of an entrepreneur is affected by his biographic and socio economics (Danwanka and Ggala 2007). However, (Doss , 2004) opined that age, marital status and religion do not have much relevance other than for policy makers to understand the demographic characteristics of the respondents.

Furthermore, the marketers socioeconomic characteristics considered in this study include age, marital status, household size, level of education, primary and secondary occupation, marketing experience and source of finance.

Table 1a: Age, household size and years of experience of pineapple marketers

\begin{tabular}{|c|c|c|c|c|c|}
\hline Variables & $\begin{array}{l}\text { Wholesalers } \\
\text { Frequency }\end{array}$ & Percentage & $\begin{array}{l}\text { Retailers } \\
\text { Variables }\end{array}$ & Frequency & Percentage \\
\hline \multicolumn{6}{|l|}{ Age } \\
\hline $20-28$ & 3 & 14.4 & $25-33$ & 11 & 25.1 \\
\hline $29-37$ & 5 & 23.8 & $34-42$ & 15 & 34.1 \\
\hline $38-46$ & 4 & 19.1 & $43-51$ & 6 & 13.6 \\
\hline $47-55$ & 7 & 33.3 & $52-60$ & 10 & 22.7 \\
\hline $56-64$ & 2 & 9.5 & $61-69$ & 2 & 4.5 \\
\hline Minimum & 20 & & Minimum & 25 & \\
\hline Maximum & 57 & & Maximum & 65 & \\
\hline Mean & 41 & & Mean & 41 & \\
\hline STD & 11 & & STD & 11 & \\
\hline \multicolumn{6}{|c|}{ Household size } \\
\hline $1-4$ & 4 & 19.1 & $1-5$ & 18 & 40.90 \\
\hline $5-8$ & 9 & 42.8 & $6-10$ & 10 & 22.6 \\
\hline $9-12$ & 3 & 14.3 & $11-15$ & 11 & 24.9 \\
\hline $13-16$ & 1 & 4.8 & $16-20$ & 4 & 9.1 \\
\hline $17-20$ & 4 & 19.1 & $21-25$ & 1 & 2.3 \\
\hline Minimum & 1 & & Minimum & 1 & \\
\hline Maximum & 20 & & Maximum & 21 & \\
\hline Mean & 10 & & Mean & 10 & \\
\hline STD & 6 & & STD & 6 & \\
\hline \multicolumn{6}{|c|}{ Years of experience } \\
\hline $3-9$ & 2 & 9.6 & $5-12$ & 13 & 29.6 \\
\hline $10-16$ & 5 & 23.8 & $13-20$ & 18 & 41 \\
\hline $17-23$ & 10 & 47.7 & $21-28$ & 5 & 11.4 \\
\hline $24-30$ & 3 & 14.3 & $29-36$ & 5 & 11.4 \\
\hline $31-37$ & 1 & 4.8 & $37-44$ & 3 & 6.8 \\
\hline Total & 21 & 100 & & 44 & 100 \\
\hline Minimum & 3 & & Minimum & 5 & \\
\hline Maximum & 37 & & Maximum & 40 & \\
\hline Mean & 19 & & Mean & 18 & \\
\hline STD & 8 & & STD & 9 & \\
\hline
\end{tabular}

Source: Field Survey 2018.

Age of the Pineapple Marketers

Age is an important factor in agricultural production and marketing enterprises. It affects the farmers and traders ability to acquire necessary inputs required for production and marketing process. For wholesalers, the result from table 1a shows that the majority $(33.3 \%)$ of the respondents were within the ages of $47-55$ years, followed by $23.8 \%$ within the age range of 29-37 years and $9.5 \%$ of age range of 56-64 years were the minimum. For the retailers, majority $(34.1 \%)$ of the respondents were within the ages of 34-42 years, followed by $25.1 \%$ within the age range of $25-33$ years and $4.5 \%$ of age range of $61-69$ years were the minimum. Majority of the marketer (both 
wholesalers and retailers) are adult because of these age group were more physically and mentally ripe for taking marketing risks and uncertainties and were more likely to be saddled with the responsibilities of managing resources earmarked for marketing activities.

\section{Household Size of the Pineapple Marketers}

Household according to National Population Commission (NPC, 2006) is a group of persons staying under same roof or in the same house. They share the same source of food and think of themselves as a unit. The result in table 2 a reveals that most of the respondents sampled were many in their households. However, in the wholesaler's side category 5-8 size had the highest members with $42.80 \%$, followed by $1-4$ and $17-20$ with $19.10 \%$ each, while $14.30 \%$ had $9-12$ and the least was households within the range of $13-16$ with only $4.8 \%$, while in the retailer's side category 1-5 size had the highest members with $40.90 \%$, followed by $11-15$ with $24.90 \%$, then $22.60 \%$ had 6-10 while $9.10 \%$ had $16-20$ size and the least was household within the range of $21-25$ with only $2.30 \%$. The mean household size for all the marketers was 10 .The result implies that most of the marketers had moderate household size which may be due to the variation in family size may be due to the polygamous nature of most of household in the study area due to culture and religion belief in their households and this tallies with (Muhammed, 2012) who found that the mean household size in the Sahel savannah zone of Nigeria. .

\section{Years of Experience of the Pineapple Marketers}

Adesina and kehinde (2008) stated that marketing experience enhances proper utilization of scarce resources, economic decision making as well as timely assessment of alternatives. The result from Table 2 a reveals that from the wholesalers, 1723 years categories were the majority with $47.70 \%, 10-16 y e a r s$ recorded $23.80 \%$ while $14.30 \%$ had 24-30years, 3-9years category had $9.60 \%$. However, 31-37years category ranked the least with $4.80 \%$. On the retailers side the result reveals that $13-$ 20years category ranked the highest with $41.00 \%$ and 37 44years category were the least with $6.80 \%$ each. This means that majority of the marketers had high years of experience in pineapple marketing. This may due to their ages and longest period spent into pineapple marketing.

Table1b: level of education and marital status of pineapple marketers

\begin{tabular}{lllll}
\hline $\begin{array}{l}\text { Variables } \\
\text { Educational level }\end{array}$ & $\begin{array}{l}\text { Wholesalers } \\
\text { Frequency }\end{array}$ & Percentage & $\begin{array}{l}\text { Retailers } \\
\text { Frequency }\end{array}$ & Percentage \\
\hline $\begin{array}{l}\text { Qur'an education } \\
\text { Primary }\end{array}$ & 6 & 28.6 & 13 & 29.5 \\
Secondary & 3 & 14.3 & 10 & 22.7 \\
Tertiary & 6 & 28.6 & 16 & 36.4 \\
Total & 6 & 28.6 & 5 & 11.4 \\
Marital status & $\mathbf{2 1}$ & $\mathbf{1 0 0}$ & $\mathbf{4 4}$ & $\mathbf{1 0 0}$ \\
Married & & & 42 & 95.5 \\
Single & 19 & 90.5 & 2 & 4.5 \\
Total & 2 & 9.5 & $\mathbf{4 4}$ & $\mathbf{1 0 0}$ \\
\hline
\end{tabular}

Source: field survey 2018.

\section{Educational Level of Pineapple Marketers}

Education is very important in all human endeavours as an avenue through which technology is imparted. Thus, Adesina and Kehinde (2008) asserted that education is important in the objective analysis of problem, planning and implementation of the decision and evaluation of the results especially if it is functional in whatever business an individual engages. The results from Table 1b also, Qur'anic education, secondary and tertiary ranked the highest for wholesalers on the study area with $28.60 \%$ each while only $14.30 \%$ represents those attended primary education. On the retailer's side, secondary education ranked the highest with $36.40 \%$ while tertiary ranked the least with only $11.40 \%$. This implies that all the marketers were literate in one way or the other meaning that education attainment is paramount in respondent's decision making.

\section{Marital Status of the Pineapple Marketers}

This means the state of an individual whether married or single. The result in Table $2 \mathrm{~b}$ shows that majority $90.50 \%$ of the respondents sampled were married while only $9.50 \%$ were single on the wholesaler's side while $95.50 \%$ married and $4.50 \%$ single on the retailer's side. This result implies that marriage is as essential in the study area as it signifies seriousness and trustworthiness in conducting marketing activities. Family labour availability and total expenses in the household maintenance are increased by marital status Dikwal (2002) observed that the significance of marriage as a source of family labour and partnership in decision making and overall management of enterprises.

\section{Marketing Margin and Marketing Efficiency Marketing margin}

Marketing margin represents the differences between price paid for pineapple by the marketers (producer price) and the price at which the pineapple was sold to the final consumers by the traders. Each category of marketer earns a sort of margin for the duties performed in the marketing channels. For the marketing margin to be more meaningful, the prices of the pineapple were expressed on per dozen basis and in monetary terms. 
Table 2: Marketing margin of pineapple marketers

\begin{tabular}{lll} 
& $\begin{array}{l}\text { Wholesalers } \\
\text { N/14.4 kg }\end{array}$ & $\begin{array}{l}\text { Retailers } \\
\text { /14.4 kg }\end{array}$ \\
\hline Sales & 793.23 & 956.74 \\
Purchase price & 634.38 & 827.08 \\
Transport cost & 50.48 & 16.59 \\
Loading/offloading & 11.11 & 9.00 \\
Cost of storage & 22.00 & 4.21 \\
Cost of market levy & 2.73 & 0.95 \\
Cost of losses & 13.44 & 7.62 \\
Marketing cost (MC) & 99.76 & 38.42 \\
Total marketing cost (TMC) & 734.14 & 865.50 \\
Gross marketing margin (GMM) & 158.85 & 129.66 \\
Net marketing margin (NMM) & 59.09 & 91.24 \\
Return on Investment (ROI) & 1.08 & 1.11 \\
Marketing margin(MM) & 20.03 & 14 \\
\hline SOur & & \\
\hline
\end{tabular}

Source: Field Survey 2018.

Table 2 shows the result on marketing margin. For the wholesalers, per $14.4 \mathrm{~kg}$ of pineapple, the purchase price was $\$ 634.38$ and the cost of marketing services was $\$ 99.76$ and the average sales was $\$ 793.23$ which give a gross marketing margin of 158.85 and a net marketing margin of 59.09. For the retailers, per $14.4 \mathrm{~kg}$ of pineapple, the purchase price was $\$ 827.08$ and the cost of marketing services was $\$ 38.42$ and the average sales was $\$ 956.74$ which give a gross marketing margin of 129.66 and a net marketing margin of 91.24 . Gross marketing margin of wholesalers 158.85 was higher than that of retailers 129.66 whereas net marketing margin of retailers 91.24 is higher than that of wholesalers $\$ 59.09$, return on investment of retailers 1.11 is also higher than that of wholesalers 1.08, and however, marketing margin of wholesalers 20.03 is higher than that of retailers 14 . This means that pineapple marketing in the study area was profitable with return on investment of 1.08 and 1.11 for wholesalers and retailers respectively, meaning that for every one naira invested for $14.4 \mathrm{~kg}$ pineapple, one will make return of 1.08 and 1.11 for wholesalers and retailers respectively.

Marketing Efficiency in Pineapple marketing

Marketing efficiency refers to the maximization of the ratio of output to input in marketing as presented in Table 3.

Table 3: Marketing efficiency of pineapple marketers

\begin{tabular}{|c|c|c|}
\hline & $\begin{array}{l}\text { Wholesalers } \\
\text { N/14.4kg }\end{array}$ & $\begin{array}{l}\text { Retailers } \\
N / 14.4 \mathrm{~kg}\end{array}$ \\
\hline Marketing cost & 99.76 & 38.42 \\
\hline Purchasing price & 634.38 & 827.08 \\
\hline Selling price & 793.23 & 956.74 \\
\hline Value added by marketing & 158.85 & 129.66 \\
\hline Marketing Efficiency & $159.23 \%$ & $337.48 \%$ \\
\hline
\end{tabular}

Source: Field Survey 2018.

The results in Table 3 show the marketing efficiency for $14.4 \mathrm{~kg}$ pineapple which is highest with $337.48 \%$ for retailers while that of wholesalers was lower with $159.23 \%$. Generally, it can be deduced that the marketing efficiency among all the market participants is higher than one hundred in all respect (i.e. both wholesalers and retailers) which implies that the system of marketing adopted by the marketer ceteris paribus will accrue more margins in their effort.

\section{Constraints of Pineapple Marketing}

The problems faced by the marketers were perishability nature of the pineapple, price fluctuation, lack of bargaining, scarcity and high cost of transportation as presented in Table 4. 
Table 4: Problems affecting pineapple marketers

\begin{tabular}{|c|c|c|c|c|c|c|}
\hline Constraints & $\begin{array}{l}\text { Wholesalers } \\
\text { Frequency }\end{array}$ & Percentage & Rank & $\begin{array}{l}\text { Retailers } \\
\text { Frequency }\end{array}$ & Percentage & Rank \\
\hline Perishable nature & 20 & 95.24 & $1^{\mathrm{st}}$ & 40 & 90.91 & $1^{\mathrm{st}}$ \\
\hline Price fluctuation & 17 & 80.95 & $2^{\text {nd }}$ & 36 & 81.82 & $3^{\text {rd }}$ \\
\hline Lack of bargaining & 15 & 71.43 & $4^{\text {th }}$ & 35 & 79.55 & $4^{\text {th }}$ \\
\hline Scarcity & 16 & 76.19 & $3^{\text {rd }}$ & 37 & 84.09 & $2^{\text {nd }}$ \\
\hline High cost of transportation & 6 & 28.57 & $6^{\text {th }}$ & 17 & 38.64 & $5^{\text {th }}$ \\
\hline Gluts & 7 & 33.33 & $5^{\text {th }}$ & 9 & 20.46 & $6^{\text {th }}$ \\
\hline
\end{tabular}

Source: Field Survey 2018.

From the study it revealed that the major constraint to pineapple marketing was perishable nature accounting for about $95.24 \%$ and $90.91 \%$ for both wholesalers and retailers respectfully, followed by price fluctuation with $80.95 \%$, scarcity had $76.19 \%$ and lack of bargaining of pineapple having $71.43 \%$. In addition, glut rank $5^{\text {th }}$ with $33.33 \% \%$ whereas high transportation cost had $28.57 \%$. For retailers, the major problem identified was also perishable nature of pineapple which accounts $90.91 \%$, followed by scarcity of pineapple with $84.09 \%$, price fluctuation is the next with $81.82 \%$, lack of bargaining accounts for $79.55 \%$, but high transport cost accounts for $38.64 \%$ whereas glut had $20.46 \%$.

Marketing of horticultural crops such as pineapple is quite complex and risky due to the perishable nature of the produce, seasonal production and bulkiness. The study revealed that the major constraint to pineapple marketing is perishability which among other things can be due to how the fruit was harvested, handled and stored.

\section{CONCLUSION}

From the findings marketing margin analysis indicated that for every $14.4 \mathrm{~kg}$ pineapple, Gross marketing margin of wholesalers $\$ 158.85$ was higher than that of retailers 129.66 whereas net marketing margin of retailers $\$ 91.24$ was higher than that of wholesalers 59.09, return on investment of retailers 1.11 which was also higher than that of wholesalers 1.08, and however, marketing margin of wholesalers 20.03 was higher than that of retailers 14 . This means that pineapple marketing in the study area was profitable .The marketing efficiency for $14.4 \mathrm{~kg}$ pineapple which was highest with $337.48 \%$ for retailers while that of wholesalers was lower with $159.23 \%$. Generally, it can be deduced that among all the market participants, the overall marketing efficiency indicates that the markets were efficient. Some challenges were identified to limit the effective marketing of pineapple in the study areas. From the survey, for wholesalers, the major constraint to pineapple marketing was perishable nature accounting for about $95.24 \%$, followed by price fluctuation with $80.95 \%$, scarcity had $76.19 \%$ and lack of bargaining of pineapple having $71.43 \%$. In addition, glut rank $5^{\text {th }}$ with $33.33 \% \%$ whereas high transportation cost had $28.57 \%$. For retailers, the major problem identified was also perishable nature of pineapple which accounts $90.91 \%$, followed by scarcity of pineapple with $84.09 \%$, price fluctuation is the next with $81.82 \%$, lack of bargaining accounts for $79.55 \%$, but high transport cost accounts for $38.64 \%$ whereas glut had $20.46 \%$.

\section{RECOMMENDATIONS}

Based on the results of the analysis, the following recommendations are made for policy intervention in marketing of pineapple

1. Provision of access to storage facilities

2. Construction of good road network to reduce damage of pineapple during transportation and plastics trays should be provided.

3. Extension services will be of importance to these marketers given their level of education. This will minimize the exploitation from buyers; increase their handling, packaging, and storage skills.

4. The marketers can also involve themselves in production activities by organizing themselves into producer cooperatives. This will increase their scale of operation, and margins by reducing purchase cost.

\section{REFERENCES}

Adessina, A. C. and Kehinde, A.I. (2008). "Economics of Wholesales Marketing of Fruits in Ibadan Metropolis of Oyo State. Nigeria". In: Umeh J. C.; Obinne, P. and Lawal L. (eds). Prospects and Challenges of Adding Value to the Agricultural Products, Proceeding of $22^{\text {nd }}$ Annual National Conference of Farm Management Association of Nigeria (FAMAN), held at University of Agriculture Makurdi, Benue State, Nigeria. $8^{\text {th }}-$ $11^{\text {th }}$ Setember, pp 51-59.

Bartholomew, D.P., Paul, R. E. and Rorbach, K.G. (2003). The pineapple "Botany, Production and Uses", University of Hawaii Manoa Honolulu, USA. CABI Publishing, CABI International, ISBN 0851995039.

Danwanka, H. A. and Ggala, C. E. (2007). "Analysis of Resources-use Efficiency in Irish Potato Production in Jos South L.G.A of Plateau State". In: Haruna, U.; Jibril, S.A, ; Mancha, Y. P. and Nasiru, M. (Eds). Consolidation of Growth and Development of Agricultural Sector, Proceeding of the $9^{\text {th }}$ Annual National Conference of the Nigerian Association of Agricultural Economists, $5^{\text {th }}-8^{\text {th }}$ November, 2007, Held at Abubakar Tafawa Balewa University Bauchi, Nigeria, pp 385389. 
Dikwal, M. M. (2002). "Economic Analysis of Small Scale Commercial Enterprises in Jos South Local Government Area of Plateau State". An Unpublished M. Sc. Thesis, Agricultural Economics and Extension Programme, Abubakar Tafawa Balewa University Bauchi. pp 78.

Doss, C. R. ; (2004). “Analysing Technology Adoption: Challenges and Limitation for Micro-Studies". Tale Centre for International and ACA Studies, Yale University.

FAO, (2009). "A Case Study of Tropical Fruits in Asia, with special reference to Mangoes and Pineapples. Committee on Commodity Problems", Joint Meeting of the Fourth Session of the Sub-group on Bananas and the Fifth Session of the Subgroup on Tropical Fruits, Rome, 9 - 11 December 2009.

FAOSTAT, (2010). [Online] Available: http://www.fao.org/ (2012)

Fawole, O. P. (2008). “Pineapple Farmers' Information Sources and Usage in Nigeria. Bulg. J. Agric. Sci., 14: pp 381-389. Department of Agricultural Extension and Rural Development, University of Ibadan, Nigeria.

Ivan, M., Drago, C. and Gorica, C. (2011). "Quality of Agricultural-Food Products as a fFactor of the Republic of Serbia's Competitiveness in International Market", African Journal of Biotechnology Vol. 10 (41): pp 7949-7952

Joy, P. P. (2010). "Benefits and Uses of Pineapple", Pineapple Research Station (Kerala Agricultural University), Vazhakulam-686 670, Muvattupuzha, Ernakulam, Kerala, India. www.kau.edu/prsvkm

Ken, I. (2009). "Africa and Nigeria Economic Outlook and Opportunities: The Role of Nigeria Diaspora", A Presentation delivered at EU-Africa Business Forum Summit London 14th May 2009.

Khalid, M. A., Abbas, M. and Saadullah, S. (2007). "Marketing System of Fruits, Margins and Export Potential in Pakistan", Pakistan Journal of Life and Social Sciences 5(1-2): pp 34-39.
Mark, A. A. (2010). "The Impact of Large-Scale Pineapple Companies on Rural Livelihoods in the Akuapim South Municipality of Ghana". Thesis submitted in partial fulfillment of the requirements for the Degree of Master of Philosophy in Culture, Environment and Sustainability Centre for Development and the Environment University of Oslo.

Muhammed, Abdu Yaro (2012) "Economics Analysis of Gum Arabic Markets In Kano State Nigeria". Unpublished PhD. thesis from the Department of Agricultural Economics and Extension Faculty of Agriculture, Bayero University Kano.

National Population Commission NPC, (2006). "Enumerators Manual”. National Population Commission. (Abuja), Federal Republic of Nigeria. pp 90-94.

Olukosi, J. O., Isitor, S. U. and Moses, O. O. (2005). "Introduction to Agricultural Marketing and Prices: Principles and Applications". Living Books Series G. U. Publishers, Abuja, Nigeria. pp 54-112.

Quijandría, G., Berrocal, J. and Lawrence, P. (1997). "La industria de la piña en Costa Rica: Análisis desostenibilidad. Centro Centroamericano de desarrollo Sostenible", [Online] Available;

http://www.incae.edu/EN/clads/publicaciones/pdf/cen707.pdf. (November 30, 2012)

Ubi W., Iqwe H., Ekpe S., Ibor O.( 2005). "Preliminary Trial of Fertilizer types on Pineapple (Ananas comosus) Grown on Coastal and Sands of Cross River State", Nigeria. Global Journal Pure and applied sci. 11(4): pp 457-460. International license viewed via https://creativecommons.org/licenses/by/4.0/ which permits unrestricted use, distribution, and reproduction in any medium, provided the original work is cited appropriately. 